\title{
MICHAEL MAIER A JEHO SPIS DE MEDICINA REGIA (1609)
}

\author{
VLADIMÍR KARPENKO
}

\section{MICHAEL MAIER AND HIS DE MEDICINA REGIA (1609)}

Michael Maier (1569, Kiel - 1622, Magdeburg), a German physician and alchemist, spent his life travelling, first to study at several universities, then in search of aristocratic supporters. He received a doctoral title in medicine in Basel. Maier wrote a number of works, the best known being his book of emblems, the Atalanta fugiens (1618). His attack on fraudulent alchemists, Examen Fucorum Pseudo-chymicorum (1617), was analysed recently. De medicina regia, his early work, was recently discovered in the Royal Library in Copenhagen, which holds what seems to be the book's only surviving copy. This book was printed 1609 in Prague, where Maier stayed for a short time between 1608 and 1610, joined the court of Emperor Rudolf II, and was elevated to the rank of Count palatine. De medicina, chemical aspects of which are the subject of this paper, turns out to be important also because its first part describes Maier's life. It helped fill certain gaps in his previously rather incomplete biography. Although Maier claimed that his aim was to prepare a universal medicine, the main part of the work deals with alchemy. Maier claims that his efforts to produce a panacea were successful, but the recipe is not found in the book. Instead, he deals with transmutational alchemy, discusses various theories of matter, and describes laboratory practices. Especially in this field, Maier draws extensively on Pseudogeber's Late Medieval Summa perfectionis magisterii. This attests to the importance of this treatise in Early Modern alchemy. Some recipes described in the De medicina are rather complicated, but all focus on achieving transmutation. References to Maier's universal medicine are limited to several case reports.

Keywords: Michael Maier - medicine - alchemy

DOI: $10.14712 / 23365730.2018 .21$

Ve druhé polovině 16 . a začátkem 17. století došlo k mimořádnému rozkvětu alchymie, což souviselo s řadou faktorů. Byly to především vědecké a technické objevy, ${ }^{1}$ mimo jiné v metalurgii, ale též v chemii, např́klad silných minerálních kyselin. ${ }^{2}$ Vynález knihtisku zvýšil dostupnost literatury ${ }^{3}$ a rovněž rostoucí zájem šlechty a bohatých měšt’anů o alchymii byl podstatný. ${ }^{4}$ Tehdy se vedle klasické transmutační alchymie, pokoušející se o umělou výrobu drahých kovů z obecných, rozšsiřila iatrochemie,${ }^{5}$ použití anorganických preparátů

1 Marie Boas Hall, The Scientific Renaissance 1450-1630, New York 1994.

2 Vladimír KarpenKo, Minulost kyseliny dusičné: voda, nebo duch?, Chemické listy 103, 2009, s. 696-703; Claus Priesner, Kyseliny, in: Claus Priesner - Karin Figala (edd.), Lexikon alchymie a hermetických věd, Praha 2006, s. 168-172.

3 Rudolf Hirsch, The Invention of Printing and the Diffusion of Alchemical and Chemical Knowledge, Chymia 3, 1957, s. 115-128.

4 Tara Nummedal, Alchemy and Authority in the Holy Roman Empire, Chicago 2007.

5 Iatrochemie bývá spojována s Paracelsem (Theophrastus von Hohenheim, 1494-1541), viz Walter PAGEL, Paracelsus: an introduction to philosophical medicine in the era of the Renaissance, Basel 1982. Její počátky jsou 
v medicíně (v rámci snahy o př́pravu univerzálního léku). Jedním z center evropské alchymie se staly Čechy rudolfínské doby. ${ }^{6}$ Do tohoto prostředí přišel nakrátko německý lékař a alchymista Michael Maier (1569-1622), jedna z nejproslulejších postav alchymie. V Praze vyšel jeho raný spis De medicina, jehož alchymickým aspektům se věnuje tato práce.

\section{Michael Maier - život a dílo}

Donedávna byl život tohoto učence znám jen částečně, a byl to právě objev dosud jediného známého výtisku knihy De medicina, ${ }^{7}$ co umožnilo zmapovat první část Maierova života. ${ }^{8}$ Maier, jehož zájem se soustřed’oval na medicínu, studoval na univerzitách v Rostocku, Frankfurtu nad Odrou a Padově; titul doktora lékařství ${ }^{9}$ získal v Basileji roku 1596 obhájením these De epilepsia. Postupně vydal řadu spisů, soudí se, že sedmnáct, ${ }^{10} \mathrm{z}$ nichž patrně nejproslulejší je kniha emblémů ${ }^{11}$ Atalanta fugiens ${ }^{12} \mathrm{z}$ roku 1618. Nedávno se také dostalo pozornosti jiné Maierově knize, Examen fucorum pseudo-chymicorum ${ }^{13} \mathrm{z}$ roku 1617, namírené proti alchymickým podvodníkům. ${ }^{14}$

Roku 1604 začal Maier společně se svým nevlastním bratrem pracovat na univerzálním léku, prričemž částí jejich práce bylo Velké Dílo, jak bývala nazývána činnost vedoucí k př́ipravě kamene filozofü. Prohlašoval, že vyrobili takový lék žluté barvy, jímž prý vyléčili řadu nemocí; závěrečná fáze Velkého Díla se jim však údajně nepovedla. Asi v polovině roku 1608 přicestoval Maier do Prahy, kde vydal dvě svá díla, spis De medicina regia

však již v díle francouzského františkána Johanna de Rupescissy (Jean de Roquetaillade, počátek 14. století až 1360/1366). Viz Leah De Vun, Prophecy, Alchemy, and the End of Times, New York 2014.

6 Ivo Purš - Vladimír KarpenKo (edd.), Alchymie a Rudolf II., Praha 2011.

7 Kodaňská královská knihovna, sign. 12-159. Karin Figala - Ulrich NeumanN, Michael Maier: New Bio-Bibliographical Material, in: Z. R. W. M. von Martels (ed.), Alchemy Revisited, Leiden 1990, s. 34-50.

8 Karin Figala - Ulrich Neumann, ,, Author, cui nomen Hermes Malavici “: New Light on the Bio-Bibliography of Michael Maier, in: Pietro Rattansi - Antonio Clericuzio, (edd.), Alchemy and Chemistry in the 16th and 17th Centuries, Dordrecht 1994, s. 121-147; Hereward Titon, The Quest for the Phoenix: Spiritual Alchemy and Rosicrucianism in the Work of Count Michael Maier (1569-1622), Berlin 2003. O Maierově pobytu v Praze: Ivo Purš - Jaroslava Hausenblasová, Michael Maier a jeho působení v Praze, in: I. Purš - V. Karpenko (edd.), Alchymie, s. 335-365.

9 Šlo o „doctoratus in utraque medicina“, který získal 4. listopadu 1596 (podrobněji o Maierově životě viz K. Figala - U. Neumann, Michael Maier, s. 38). Maierova teze obhájená 27. října 1596 vyšla v Basileji tiskem Konráda Waldkircha.

10 Seznam Maierových děl uvádí Ivo Purš, Michael Maier: Jeho život a dílo v recentní literatuře, Studia Rudolphina 2, 2002, s. 58-67.

11 Tradici knih emblémů založil italský humanista Andreas Alciatus (1492-1550) dílem Emblematum liber. Je v nich krátké heslo, obraz a epigram, ale každá část je nesrozumitelná sama o sobě. Mezi stovkami takových děl jsou pouhá tři s alchymickou tematikou. Kromě Maierovy Atalanty jsou to dvě knihy českého exulanta Daniela Stolcia Viridarium chymicum, Frankfurt 1624, a Hortulus Hermeticus Flosculis Philosophorum, Frankfurt 1627.

12 Český překlad Jakuba Hlaváčka a Iva Purše: Michael MAIER, Prchající Atalanta, Praha 2006.

13 Překlad a rozbor Wolfgang BECK, Michael Maiers Examen Fucorum Pseudo-chymicorum - Eine Schrift wider die falschen Alchemisten, disertace, Technische Universität München 1991.

14 Dílo navazuje na kritiku podvodníků, jak ji shrnul lékař a alchymista Heinrich KHUNRATH (1560-1605) ve svém díle Vom hylealischen [...] Chaos z roku 1597. Maier z něj vyšel, zčásti celé pasáže doslovně citoval, př́ipadně ještě doplnil. Podrobněji o tomto Khunratovu spisu viz Vladimír KaRPENKo, Heinrich Khunraths Vom hylealischen Chaos: chemische Aspekte, Studia Rudolphina 15, 2015, s. 88-107. 
a navazující veršované dílo Hymnosophia. ${ }^{15} \mathrm{Na}$ př́mluvu vlivných aristokratů přijal Maiera císař Rudolf II. a učinil ho svým dvořanem, ovšem bez bližší specifikace. Navíc není žádný doklad toho, že by Maier byl lékařem Rudolfa II. Již 29. 9. 1609 ho panovník povýšil do dědičného šlechtického stavu s titulem comes palatinus. Maier opustil Prahu patrně v létě roku 1610. Vyhledával pak další mecenáše a zemřel v Magdeburgu, kde jeho archiv shořel při požáru města. ${ }^{16}$

Maierova De medicina regia, ${ }^{17}$ vydaná roku 1609 v Praze, je autorovým raným spisem. Jeho význam je mnohostranný: je to biografie a současně náhled na počáteční období Maierova laborování. Dílo je rozčleněno na tři knihy: první líčí především autorův život, druhá a třetí jsou výklady o výrobě a aplikaci Maierova léku, především o alchymických aspektech celého procesu. Pokud jde o medicínu, jsou v díle uvedeny jednoduché kasuistiky, nikoli však návod, jak univerzální lék vyrobit.

\section{Maier jako teoretik}

Zásadním problémem studia alchymických spisů je jejich jazyk, který se vyvíjel po staletí, kdy nebylo známé chemické složení používaných substancí. Názvy sloučenin se nejčastěji odvozovaly od vnějších charakteristik jako je barva, struktura krystalů, ${ }^{18}$ ale také chut'. ${ }^{19}$ Alchymie rovněž stále více používala různé symboly, ${ }^{20}$ takže postupně byl stav natolik nepřehledný, že se začaly objevovat terminologické lexikony. ${ }^{21}$ Tato složitost souvisela s dalším rysem alchymie, totiž s utajováním. To lze nalézt již v helénistické alchymii v prvních staletích našeho letopočtu, stejně jako později v alchymii arabské, kde se navíc objevila disperze informace, kdy autor uvedl část návodu $\mathrm{v}$ jednom, zbytek v jiném díle. To pokračovalo v Evropě, kde se alchymie objevila přibližně v polovině 12 . století.

Maier, přesvědčený alchymista pokládající se za mistra této nauky, to ve své knize konstatuje slovy: ${ }^{22}$ „tato kniha je tedy vydána tak, jakoby vůbec vydána nebyla“. V druhé kni-

15 Hymnosophia, seu Meditatio laudis divinae, pro Coelidonia medicina mystica Vorchadumica, pie instituta (s. 1., s. a.), soubor čtyřiceti básní věnovaných chvále Boha za „mystický lék“.

16 Prokázal to J. B. Craven; město bylo spáleno poté, co ho v květnu 1631 dobyly jednotky císařského polního maršála Tillyho (James Brown Craven, Count Michael Maier, Berwick /Maine/ 1914, s. 8).

17 De medicina regia \& verè Heroica, Coelidonia, (Quae\&Phalaia, Aurelia aurea, Lapis sanitatis philosophicus, Sulfur auri, Rex Fontiam ingrediens, multisq; alijs nominibus dicta innotuit) eiusq; modo inventionis, essentiâ, viribus \& usu, Tùm corporibus humanis fecilitèr medendis, tùm alijs cum fructu experimentandis, Tractatus utilissimus, Authore Michaele Maiero Philos: et Med: Doctore, P. C. CAESAREO. [4º, 99 s.] (dále jako De medicina).

18 Typické jsou sírany dvojmocných kovů dodnes v triviálním názvosloví označované jako skalice, starším termínem ,vitrioly“ (z latinského „vitrum“, sklo), jejichž krystaly připomínají kousky skla. Navíc je v tomto případě dalším kritériem barva: modrý vitriol, $\mathrm{CuSO}_{4}$, zelený vitriol $\mathrm{FeSO}_{4}$, jindy naleziště, goslarský vitriol, rímský vitriol.

19 Již ve starověku byl např́íklad ,saccharum saturni“ octan olovnatý, sladké chuti. Olovo bylo kovem Saturnu.

20 Jako charakteristický př́klad může posloužit termín ,„aquila alba“, označující chlorid amonný. Ten snadno sublimuje, proto „orel“, a je bílý (,albus“). Běžně se v obrazovém doprovodu zobrazovala tato sůl jako dravý pták. Podrobné zpracování jazyka a symboliky alchymie viz Maurice Crosland, Historical Studies in the Language of Chemistry, London 1962.

21 Např́klad Martin Ruland (ml.), Lexicon Alchemiae sive Dictionarium Alchemisticum, Francofurti 1612; o něm podrobněji Vladimír KARPENKo, Martin Rulands Lexicon alchemiae im Kontext der chemischen Sprache und Systematik, Studia Rudolphina 11, 2011, s. 102-126.

22 De medicina, *r. 
ze naopak přiznává nepříznivý výsledek zmíněných faktorů: ${ }^{23}$ „Měl jsem pocit, že jeden a tentýž autor (abych nehovořil o autorech různých) se věcně ani verbálně neshoduje ani s jinými autory, ani sám se sebou."

To současně dokládá, že Maier prostudoval různé alchymické spisy, a potvrzuje to i výčet autorit této nauky, které pokládal za nejpovolanější. ${ }^{24}$ Ze seznamu dvaceti devíti jmen uvedeme některá. Vedle Johanna Rupescissy to jsou např́klad Albert Veliký, ${ }^{25}$ Raymundus Lullus, ${ }^{26}$ Arnald z Villanovy ${ }^{27}$ a nechybí ani Basil Valentin. ${ }^{28}$ Uvedení posledně jmenovaného dokazuje, že Maier znal i tehdy zcela nové prameny. O to více překvapuje, že ve výčtu chybí jeho současník Andreas Libavius, ${ }^{29}$ jehož kniha Alchemia ${ }^{30}$ obsahuje detailní a vcelku srozumitelný popis laboratorních technik a návodů na prrípravu různých sloučenin.

Ještě překvapivěji chybí v seznamu jméno Gebera, autora, kterého Maier nejvíce citoval. Především spis Summa perfectionis magisterii, jehož vznik se datuje krátce po roce 1300. Od svého vzniku byla Summa mimořádně vlivným dílem, uznávaným i po třech staletích. Původně byl za autora tohoto a čtyř dalších spisů ${ }^{31}$ pokládán arabský alchymista Džábir ${ }^{32}$ (v latině Geber). ${ }^{33}$ Je prokázáno, že jde o dílo evropské provenience, pouze ovlivněné arabskými prameny. ${ }^{34}$ Celý soubor pěti spisů bývá dnes uváděn jako Pseudogeberův korpus.

23 Tamtéž, Aiijv (paginace díla používá kombinaci velkých písmen a římských číslic).

24 Tamtéž, Ciijr.

25 Albert hrabě z Bollstädtu (před 1200-1280), známý jako „doctor Universalis“, německý dominikán; alchymické spisy pod jeho jménem jsou pseudoepigrafické, ovšem on sám nepopíral možnost transmutace (William Newman, Promethean Ambitions, Chicago 2004, kap. 2).

26 Ramón Lull (kolem 1232-1315/1316), Katalánec, filozof a náboženský mystik (Antonio CLERICUZIO, Lullus, in: C. Priesner - K. Figala /edd./, Lexikon alchymie, s. 187-189). Alchymické spisy pod jeho jménem jsou pseudoepigrafické. Jejich seznam viz Michela Pereira, The Alchemical Corpus Attributed to Raymond Lull, London 1989.

27 Arnald z Villanovy (asi 1240-1311), Katalánec, lékař a diplomat dlouho pokládaný za alchymistu, ovšem díla z této oblasti vydaná pod jeho jménem jsou pseudoepigrafy (Gundolf KeIL, Arnald z Villanovy, in: C. Priesner K. Figala (edd.), Lexikon alchymie, s. 48-49).

28 Basilius Valentinus (z řec. „basileus“/král/ a lat. „valens“/mocný/), pseudonym autora proslulých alchymických spisů. Údajně benediktinský mnich v Erfurtu ve 14. nebo 15. století. Z děl pod jeho jménem lze uvést raný a velmi vlivný spis Triumph Wagen Antimonii (1604), zájmu se těšil také Letztes Testament (1626). Vydal je a zřejmě i sepsal Johann Thölde (zemřel před 1624), horní hejtman knížectví Bamberg (Claus PRIESNER, Johann Thoelde und die Schriften des Basilius Valentinus, Wolfenbütteler Forschungen, sv. 32, 1986, s. 107).

29 Andreas Libavius (vlastním jménem Li[e]bau, po r. 1555-1616), německý pedagog, lékař a alchymista, autor četných spisů. Wolf-Dieter Müller-JAHNCKE, Libavius, in: C. Priesner - K. Figala (edd.), Lexikon alchymie, s. 184; Libaviův život a dílo viz Bruce T. Moran, Andreas Libavius and the Transformation of Alchemy, Sagamore Beach 2007.

30 Moderní překlad Die Alchemie des Andreas Libavius. Ein Lehrbuch der Chemie aus dem Jahre 1597, Weinheim 1964 (dále jako A. LiBavius, Alchemie).

31 De investigatione perfectionis, De inventione (veritatis), Liber fornacum nebo Liber de fornacibus a Testamentum.

32 Džábir ibn Hajján je problematická postava; dodnes není jasné, zda někdo takový vůbec žil (udává se někdy letopočet 721/722 ? - 815 ?). Paul Kraus, Jābir ibn Hayyān: Contributions à l'Histoire des Ideés Scientifiques dans l'Islam, I, Cairo 1942, s. XXVII.

33 Samotnou Summu podrobně analyzoval William R. Newman, The Summa Perfectionis of Pseudo-Geber. A Critical Edition, Translation, and Study, Leiden 1991. Komentovaný překlad celého korpusu Ernst DARMSTAEDTER, Die Alchemie des Geber, Berlin 1922; česky Ernst DarmstaedTER, Geberova alchymie, přel. Pavel Krummer, Praha 2012.

34 Summa byla snad dílem františkána Paula z Tarenta, zbývající spisy korpusu napsali jiní autoři, dodnes neznámí. Viz William R. Newman, New Light on the Identity of Geber, Sudhoffs Archiv 69, 1985, s. 76-90. 
Maier vycházel z řady pramenů a jeho teoretické představy a pasáže popisující laboratorní praxi jsou rozptýleny hlavně v druhé a třetí knize De medicina regia. V těchto výkladech najdeme všechny tři hlavní teorie alchymie týkající se složení hmoty obecně a hlavně kovů. V první knize píše: ${ }^{35}$ „št’astnou náhodou jsem objevil nauku o živlech“", ${ }^{36}$ není však jasné, o jaké živly, elementy, se jedná. Jinde specifikuje: ${ }^{37}$ „Pravím, že jsou čtyři jednoduché živly, jejichž smísením ${ }^{38}$ se skládají těla různých druhư", což je zřetelná narážka na aristotelskou představu čtyř elementů. ${ }^{39}$ Maier používá termín composita corpora, což by měla být, ,smíšená těla“. Pak by to mohla být poněkud zkomolená narážka na Pseudogeberovu Summu, kde se uvádí, že částice čtyř elementů, minimae partes, vytvářejí fortissima compositio. ${ }^{40}$

Ve výkladech o kovech se objevuje i druhá hlavní teorie alchymistů, totiž merkurosulfurová. Když se zabývá složením zlata, Maier cituje Summu, jejíž text poněkud upravuje. ${ }^{41}$ Text Summy začíná: ${ }^{42}$ „Sol [zlato] tudiž je vytvořen z nejjemnější, fixní a nejjasnější substance rtuti, a z trochy substance čisté, fixni siry slabé červenosti, změněné ze své vlastní podstaty, a zbarvujici ho [zlato]. Tudiž, protože se rozličnost v barvách sulfuru vyskytuje, je nezbytné, že žlutost zlata má také rozličnost. “ Maier přidává větu: „Přeci však [zlato] obsahuje větši množství živého stř́bra. "Podle merkurosulfurové teorie měly být kovy tvořeny merkuriem a sulfurem, elementárními substancemi, netotožnými se skutečnými př́rodními látkami; proto je nenazýváme rtut', respektive síra. Podle této teorie měl mít každý kov vlastní merkurius a vlastní sulfur, přičemž se tyto složky lišily podle kvality kovu - ve zlatu byly nejdokonalejší, v olovu naopak nejhorší. 43

Třetí z alchymických koncepcí, Paracelsova představa tria prima, ${ }^{44}$ se objevuje v De medicina $\mathrm{v}$ širší souvislosti, kdy se autor zabývá otázkou vzniku kovů v př́rodě, jejich ,,rozením“ a „zráním“. Názor, že se kovy v nitru země rodí a zrají do ušlechtilejší podoby, kterou je v posledku zlato, je starého data a byl živý ještě v 17 . století. ${ }^{45}$ Maier se navíc přikláněl

35 De medicina, Aiiijr.

36 V originále, ,elementa“.

37 De medicina, Dijv.

38 „Mixta“ jsou u Aristotela látky homogenní, nikoli směsi v dnešním pojetí.

39 Její kořeny jsou starší; čtveřici oheň, voda, země a vzduch uvažoval již Empedoklés z Akragantu (493? - 433 př. n. 1.). Viz Bernard Pullman, The Atom in the History of Human Thought, Oxford 1998.

40 W. R. Newman, The Summa Perfectionis, kap. 4.; Lawrence M. PrinciPe, The Secrets of Alchemy, Chicago 2013, s. 57. Tyto „nejdrobnější části“ údajně byly dělitelné a nebyly trvalé. V různých kovech měly mít rozdílné velikosti, ve zlatě byly nejmenší, v olovu největší. V olovu tak mezi nimi zůstávaly velké mezery, jimiž mohl pronikat oheň, a proto se tento kov snadno taví a v ohni mění (oxiduje). Naopak částice zlata se mohly složit velmi kompaktně, kov je proto značně inertní. Newman překládá slovo „pars“ jako částice.

41 De medicina, Iv.

42 W. R. Newman, The Summa Perfectionis, s. 471/725 (první údaj je stránka latinského originálu, druhá anglického překladu).

43 Tato teorie tradičně připisovaná Džábirovi (o něm výše) je ve skutečnosti staršího data, vzniklá modifikací aristotelských představ. Její výklad uvedl Avicenna (Abú 'Alí 'l-Husajn ibn 'Abdalláh ibn 'Alí ibn Síná, 980-1037) v díle Kitāb aš-šifá’ (Kniha uzdravení; míněno z nevědomosti). On sám v možnost transmutace kovů nevěřil. Karl GARBERS - Jost Weyer, Quellengeschichtliches Lesebuch zur Chemie und Alchemie der Araber im Mittelalter, Hamburg 1980, s. 36.

44 Paracelsus modifikoval merkurosulfurovou teorii tím, že k merkuriu a sulfuru přidal další elementární složku, sůl (,sal“). Tato trojice měla být základem veškeré hmoty, ale Paracelsus rozšíril tuto úvahu - mělo jít současně o odraz nebeské nehmotné Trojice a také o trojici lidské podstaty, kterou byly tělo, duše a duch (W. PAGEL, Paracelsus, s. 82).

45 Mircea Eliade, Kováři a alchymisté, Praha 2000, kapitola 4. Slitiny zlata různého odstínu se od starověku občas vysvětlovaly neúplným ,dozráním“ tohoto kovu (Andrew RAmAGE - Paul CRADDOck, King Croesus ' Gold, Cambridge /Mass./ 2000, s. 31), takže ještě Maier psal o „rozličné žlutosti zlata“. 
k myšlence „semene“, určitého zárodku, z něhož by kov klíčil. To později rozvedl ve své knize Atalanta fugiens ${ }^{46}$ a tyto představy měly v Evropě mocnou oporu v novozákonním textu. ${ }^{47}$

V De medicina přidává Maier ještě další analogii, totiž představu těla, duše a ducha hmoty, takže podle něj se „„ělo“, tedy hmota, ukáže ,skrze duši a duše skrze ducha, to znamená sal skrze sulfur a sulfur skrze merkur". To je paralela, v níž jsou paracelsovské elementy hierarchicky seřazeny. Názor, že kovy měly mít kromě těla také duši a ducha, se rovněž rodil již v helénistické alchymii. Později se v Evropě zmiňoval proces exanimatio jako odnětí duše kovu, obvykle jeho převedením na sloučeninu. Když polemizuje s některými alchymisty, Maier píše, že „naše magnesie“, 48 zřejmě jeho zázračný lék, má tři principy, které vyjmenovává jako sal, sulfur a merkurius. ${ }^{49}$ Vzápětí však pokračuje kriticky o alchymistech hovořících o ,přeludech chemie, $t j$. o solích, sulfurech a merkurech“, když přece klíčová je pátá bytnost (kvintesence), což je představa aristotelská.

Quinta essentia, česky kvintesence (ve staré češtině pátá bytnost), sehrála významnou úlohu v evropské alchymii. Podle Aristotela to měla být věčná, neměnná složka (nazýval ji aithér), z níž měl být vytvořen supralunární prostor, včetně planet a hvězd. Tím, že byla neměnná a věčná, lišila se od čtveřice elementů schopných vzájemné přeměny. ${ }^{50}$ Ty tvořily sublunární svět, který je v důsledku této možnosti proměnný. Sama koncepce kvintesence doznala hluboké transformace vlivem Johanna z Rupescissy, jehož názor ${ }^{51}$ se stal určujícím pro následující staletí. Jeho úvahy o kvintesenci přejal i Maier.

Rupescissa prohlašoval, že kvintesence, př́tomná podle Aristotela pouze v supralunárním prostoru, se dostává v malém množství na zem, jen je nutné ji zachytit, a dospěl $\mathrm{k}$ závěru, že je to alkohol získaný destilací vína. ${ }^{52}$ Podle jeho názoru se měly právě $\mathrm{v}$ alkoholu nechat vyluhovat různé byliny a tento výluh se měl předestilovat, což byla novinka. Do té doby byly běžné výluhy do vína, které doporučoval napríklad Arnald z Villanovy, ovšem bez následné destilace. Rupescissa postupně rozšiřoval spektrum látek a doporučoval v kvintesenci, alkoholu, rozpouštět i látky anorganické, kovy, posléze také soli. Soudil, že to jsou kvintesence daných látek. ${ }^{53} \mathrm{~V}$ každém př́ípadě však právě použití anorganických látek v medicíně bylo počátkem iatrochemie, o jejíž definitivní prosazení se o dvě století později zasloužil Paracelsus.

46 Epigram k Emblému VI.: „Filozofové učí, že zlato má být rozhazováno / na sněhových polích, podobajících se tenkým listům. / Abys to učinil, dobře pozoruj, nebot' jako v zrcadle / uvidíš, že zlato klíčí jako pšenice.“

47 J 12:24: „Amen, amen, pravím vám, jestliže pšeničné zrno nezapadne do země a nezemře, zůstane samo. Zemře-li však, vydá mnohý užitek."

48 Termín pocházející z arabského „maghnísijá“, původního krycího jména pro kyzy, měl mnoho významů a patř̌́ k problematickým v jazyce alchymie. V Maierově době Rulandův lexikon (M. Ruland (ml.), Lexicon Alchemiae, s. 318) uvádí pět vysvětlení termínu magnesia, z toho dvě mineralogická. Maierovo označení zázračného léku tímto termínem je další z krycích jmen, v této souvislosti méně typické (o krycích jménech, jednom ze způsobů utajování v alchymii, viz Lawrence M. PrinciPe, Krycí jména, in: C. Priesner - K. Figala (edd.), Lexikon alchymie, s. 158-160).

49 De medicina, Dijr.

50 Soudilo se, že element mohl být proměněn v kterýkoli ze tři zbývajících bud' přímo oheň $\rightarrow$ vzduch $\rightarrow$ voda $\rightarrow$ země $\rightarrow$ oheň $\rightarrow$. ., nebo změnou jedné z kvalit: oheň (horký, suchý) $\rightarrow$ vzduch (horký, vlhký) $\rightarrow$ voda (vlhká, chladná) $\rightarrow$ země (chladná, suchá) $\rightarrow$ oheň (horký, suchý) $\rightarrow$... Představa možné proměny elementů nabízela teoretické zdůvodnění možnosti transmutace.

51 Šlo o dílo De consideratione quintae essentiae omnium rerum (1351-1352, poprvé tiskem Benátky 1514).

52 Stal se prvním, kdo alkohol takto, jako „kvintesenci“, př́ípadně „kvintesenci vína“ označil. Po objevu, asi v polovině 12. století, byl alkohol nazýván ,aqua ardens“, později pak ,aqua vitae“ nebo „spiritus vini“.

53 Například kvintesence zlata se měla připravovat ponořením rozžhaveného zlatého plíšku do alkoholu. 
V De medicina se píše, že pátá esence „sama je vodou, jež dokonale odstraňuje trvalou horečku“, 54 jejíž příčinou je podle Maiera zkažená krev a štávy vznikající z ní, což je narážka na starověkou humorální teorii. Podstatné je, že nepříznivý stav organismu lze prý napravit podáním páté esence. Pokračování textu je obrazem nejasností v souvislosti s kvintesencí, jaké stále panovaly v Maierově době: „Avšak voda, která hoři, ${ }^{55}$ v zásadě není zbavena tepla a čtyř živlì [...].“ Druhá část věty je narážkou na čtyři aristotelské elementy.

Následující doporučení páté esence zlata či perel jako léčivého preparátu dokresluje významový posun termínu kvintesence od původního aristotelského pojetí. Posléze Maier uvádí př́značné použití alkoholu jako nosiče, v němž se rozpouštěly podávané léky. Cituje z Pseudolullyho: ${ }^{56}$ „Stejným způsobem používá Lullus pátou esenci proti tř́denní horečce $i$ horečce každodenní, jakož i proti všem ostatním, akutním i chronickým a na všechny ostatni príznaky a nemoci. Vždy je smíšena s př́slušnými léky, jež jsou na prodej v lékárnách a běžně se předepisuji. “ Dále pokračuje: ${ }^{77}$ „Pokud chceš správně léčit, vezmi zcela pročištěnou pátou esenci lidské krve. "58

\section{Praxe v laboratoriu}

Maierovým cílem byl univerzální lék, ale v pasážích věnovaných praktickému laborování nalézáme úvahy týkající se obecně kamene filozofů. Přitom je nutno počítat s méně přehledným názvoslovím. Setkáváme se s označením Kámen, materie, elixír, tinktura, př́ípadně medicína, když poslední uvedený termín je určen především léku, o jehož přípravu se Maier pokoušel. Ovšem stejné označení používal Pseudogeber ve smyslu kámen filozofů, agens transmutující kovy. Je tudíž nutné řídit se kontextem.

Maierova diskuse mechanismu účinku kamene filozofư ${ }^{59}$ naznačuje, že autor rozlišuje universální a partikulární proces, když v prvním z nich se kámen sám sebou v procesu transmutace kovů zmnožuje nebo alespoň zůstává zachován, ve druhém transmutuje jen určitý kov, takže pro každý typ transmutace byl potřebný jiný kámen. Jindy však býval jako partikulární označován kámen, který dokázal transmutovat pouze určité omezené množství obecného kovu a přitom se spotřeboval, ztrácel ve výsledném produktu. Maier upozorňuje, ${ }^{60}$ že lék, míněno univerzální, není shodný s transmutující ,universálni tinkturou“, která proměňuje obecné kovy ve zlato: ${ }^{61}$ „Nepopírám však, že tento lék má obrovskou schopnost léčit nemoci a upevňovat zdraví. Vždyt' co mají společného lidská těla s kovy a naopak? Kovy jsou pevné, složené, ${ }^{62}$ nejsou plné žil a št’áv a chybí jim život

54 De medicina, Dv.

55 V originále ,aqua ardens“, alkohol. Viz výše.

56 De medicina, Dijr.

57 De medicina, Dijv.

58 Lidskou krev destiloval např́klad Arnald z Villanovy. Jak uvedl, získal element vodu, což byla skutečně převážně obyčejná voda, dále žlutavou kapalinu, kterou označil jako „vzduch“ a destilát červené barvy, podle něj „oheň“. Složení těchto produktů nelze spolehlivě určit; závisí na podmínkách destilace (Hans-Werner ScHüTT, Auf der Suche nach dem Stein der Weisen. Die Geschichte der Alchemie, München 2000, s. 285).

59 De medicina, Hiiijr až Ir.

60 Tamtéž, Ciiijr.

61 Tamtéž, Ciiijv.

62 V originále „compacta“. 
a úkony vlastní částem těla, zatímco naše těla jsou organická, živá, obdařená duši a mají své specifické vlastnosti, jimiž se odlišují od mineráli̊, rostlin a ostatních živočichư." Kdyby prý však byl kámen filozofů přiveden k dokonalosti, což je dlouhodobá a nákladná činnost, pak podle Maiera takový preparát uzdravuje nemocné lidi stejně jako nedokonalé, tedy nemocné kovy. ${ }^{63}$

Zajímavý je popis laboratorních technik, vycházející ve většině z Pseudogeberovy Summy, avšak Maier ji necituje pokaždé. Výčet laboratorních technik začíná sublimací, kde autor rozlišuje její tělesnou a spirituální formu, ale blíže to nekomentuje. ${ }^{64}$ Současně se zmiňuje o sirné slanosti, což může být narážka na Summu: ${ }^{65}$,Př́ččina tohoto objevu byla, že ani naši předchůdci, ani my, ani ti kdo po nás přijdou, nenaleznou ničeho jiného, co by s těly spojeno bylo, než duchy samé, nebo cokoli by v sobě zahrnovalo povahu těla nebo ducha." Pseudogeber upozorňuje na různorodost druhů a jejich vliv na těla; některá hoří (síra, arsenik, markazit), ${ }^{66}$ přičemž první dvě látky jsou podle něj ,duchové““ a zcela se rozpadají. Jiné nehoří, jako třeba všechny druhy tutije. ${ }^{67}$ Příčinou hoření je ,hořlavá olejovitost sirnatosti" 68 takže se látka snadno vznítí. „Když oheň roste, vždy to s sebou pozvedá malé částice; tudiž to za sebou zanechává větší ", což připomíná Pseudogeberovy korpuskulární představy, v nichž hrála roli velikost částic, přičemž rozdílem v ní se vysvětlovaly různé procesy. Maier zřejmě tyto úvahy částečně přebíral.

V diskusi o kalcinaci, žíhání látek na vysoké teploty, se Maier př́mo odvolává na Summu a píše, že je to ,zpráškováni ohněm, kdy je věc zbavena zpevňující vlhkosti. Byla vynalezena proto, aby byla ohněm zničena ničivá a vysilující ${ }^{69}$ sirnatost. “70 Výklad Summy je však podstatně podrobnější. ${ }^{71}$ Následující Maierova formulace není příliš jasná: „Filozofové však zmiňuji i jiný druh kalcinace, při niž se odnímá zemitost a ohnivost, aby byla tělu navrácena prvotní studená, vodnatá a spalujíci 72 vlhkost. " Podobnou terminologii používal později Robert Boyle (1627-1691), když popisoval srážecí reakce v roztoku, což by mohl být tento př́pad. ${ }^{73}$ Typická reakce tohoto typu byla prakticky aplikována nejpozději od 16. století, kdy se kyselina dusičná používaná v prubířství zbavovala nežádoucí příměsi kyseliny chlorovodíkové74

63 De medicina, Hiijv.

64 Tamtéž, Diiijr.

65 William R. Newman, The Summa Perfectionis, s. 357/681.

$66 \mathrm{Z}$ uvedené trojice hoří jen síra. Arsenik byly oxidy a sulfidy tohoto kovu: „arsenicum album“, oxid arsenitý $\left(\mathrm{As}_{2} \mathrm{O}_{3}\right)$, ,arsenicum citrinum“, žlutý sulfid arsenitý $\left(\mathrm{As}_{2} \mathrm{~S}_{3}\right)$, prrípadně ,,arsenicum rubrum“, červený tetrasulfid tetraarsenu $\left(\mathrm{As}_{4} \mathrm{~S}_{4},\right)$. Tyto sloučeniny sublimují (oxid) nebo se při vyšší teplotě rozkládají (sulfidy) na oxid arsenitý a oxid siřičitý. „Markasit“ býval v Pseudogeberově době obvykle disulfid železa $\left(\mathrm{FeS}_{2}\right)$, pyrit, $_{\text {, }}$ terý nehoří.

$67 \mathrm{Z}$ arabského ,tutíjá“. Obvykle oxid zinečnatý $(\mathrm{ZnO})$, bud' záměrně připravený, běžně také bílý nálet na stěnách pecí na výrobu mosazi z mědi a zinku. Obrat „,všechny druhy“ spíš naznačuje různý stupeň čistoty preparátu.

68 V originále, sulphureitas“.

69 V originále, ,defaedo“, patrně ,defatigo“.

70 Opakované zmínky o síře, přesněji „sulfuru“, či „sirnatosti“ jako spíše negativní složce připomínají, že v tehdejších představách byl klíčovou složkou kovů „merkurius“, at’ již merkurosulfurové teorie, nebo ,tria prima“. Sulfur byl sice nezbytný, ale ve větším množství spíše rušivý element.

71 William R. Newman, The Summa Perfectionis, s. 417/704.

72 V originále,,adustiva“.

73 Robert Boyle, Experiments, Notes \&c. about the Mechanical Origin or Production of Divers Particular Qualities, in: Thomas Birch (ed.), Robert Boyle, Works, London 1772, Vol. 4, s. 329.

74 Ta vznikala tehdy, pokud byl výchozí dusičnan draselný kontaminován chloridem draselným, což nebylo vzácné. V prubířství by kyselina chlorovodíková jako příměs dusičné vytvořila lučavku královskou rozpouštějící zlato, což by zkreslovalo kvantitativní stanovení obsahu zlata ve zkoumané slitině. 
tak, že se do ní vhodil kousek stř́bra. ${ }^{75}$ To reaguje s kyselinou chlorovodíkovou na málo rozpustný chlorid stříbrný, který vypadává z roztoku jako bílá sraženina, což vzdáleně připomíná některé práškové oxidy kovů připravované kalcinováním.

Maierův výklad rozpouštění, v němž se odvolává na Kálida, ${ }^{76}$ není jasný. Dalš́i technika, fixace,${ }^{77}$ je uvedena podle Pseudogebera, ${ }^{78}$ jehož však Maier tentokrát necituje a výklad zkracuje. Maierův výklad týkající se destilace je krátká pasáž ze Summy, ${ }^{79}$ citovaná prakticky doslovně, opět však není uveden tento pramen. Totéž platí pro popis koagulace, tedy srážení, včetně absentujícího udání pramene. Text je uveden větou totožnou se Summou, ${ }^{80}$ ovšem sám tento proces býval pojednáván složitěji.

Podobně dvě Maierovy věty týkající se zvoskovatění ${ }^{81}$ jsou prakticky totožné se Summou, ${ }^{82}$ která opět není citována. Libaviův výklad, kde je proces nazýván inceratio, je podrobnější. Začíná definicí:83 „Incerace je smíchání vlhkosti se suchou látkou skrze pomalé Kombibieren až do konsistence opět změklého vosku. "Descensi (destillatio per descensum) Maier krátce zmiňuje s tím, že jde o významnou operaci, bez níž by ostatní postupy neměly cenu, ale popis vlastního provedení slibuje uvést na jiném místě knihy, což však nečiní. Připomíná, že je to proces, jenž se podle Gebera blíží sublimaci. ${ }^{84}$ Descense byla blízká oddělování stř́ibra ze slitiny s mědí. ${ }^{85}$

V praktických pasážích uvádí Maier také několik návodů, vesměs složitých a obtížně interpretovatelných, což je pro alchymické návody typické, ale především všechny patří mezi experimenty směřující k údajné transmutaci. Hlavně však - v knize není žádný návod na jeho univerzální lék. Jako př́iklad lze uvést nejjednodušší návod, kdy se autor zmiňuje o tom, že podnikl pokus spočívající „ve žlucení střibra pomocí povýšené vody neboli tinktury, který se nezdařil ${ }^{\prime}$. 86 Můžeme se ho pokusit jen přibližně rekonstruovat, přičemž uvedeme některé možnosti vysvětlení s použitím dobových pramenů. Ve skutečnosti nešlo vůbec o transmutaci kovů, ale o povrchové barvení stř́ibra, aby připomínalo zlato. Přehlednější je analogický Paracelsův návod na „povýšení Luny“, 87 jímž Maierův text upřes-

75 Podrobně popsal tento postup Biringuccio, The Pirotechnia of Vannoccio Biringuccio, přel. C. S. Smith a M. T. Gnudi, New York 1990, s. 186.

76 Chálid ibn Jazíd ibn Muáwija (asi 660-704), syn chalífy Jazída I. Alchymické spisy pod jeho jménem jsou pseudoepigrafy (Manfred Ullmann, Die Natur- und Geheimwissenschaften im Islam, Leiden 1972, s. 192).

77 De medicina, Er. Cílem této operace bylo učinit těkavé látky netěkavými, obvykle jejich zreagováním na vhodné sloučeniny. Nejvíce „fixním“ kovem bylo zlato, jak známo málo chemicky reaktivní.

78 William R. Newman, The Summa Perfectionis, s. 448/716.

79 Tamtéž, s. 408/700.

80 Tamtéž, s. 436/711.

81 De medicina, Ev.

82 William R. Newman, The Summa Perfectionis, s. 453/718.

83 A. Libavius, Alchemie, s. 91.

84 William R. Newman, The Summa Perfectionis, s. 403/698: ,vezme se descensorium, do něj se vloží substance, zakryje se víkem a utěsní hlínou. Pak se rozdělá oheň. Destilát vytéká otvorem do podstavené nádoby“, ale není zmínka o tom, že by se proces blížil sublimaci. Možná, že Maiera ovlivnil sled kapitol, protože této předchází v Summě pasáž o sublimaci na s. 400/697.

85 Bylo to „vycezování“, („ságrování“, z německého „saigern“). Poměrně složitý proces oddělování stř́ibra od mědi tavením (Lazarus ERCKER, Beschreibung Allerfürnemisten Mineralischen Ertzt, Prag 1574, fol. 105r a dále).

86 De medicina, Aijr.

87 Arthur E. WAITE, The Hermetic and Alchemical Writings of Paracelsus the Great, I, Edmonds (WA) 1992, s. 319. 
níme. Výchozí směs obsahuje sal ammoniac (chlorid amonný, $\mathrm{NH}_{4} \mathrm{Cl}$ ), kamenec (síran draselno-hlinitý), flos aeris (nejčastěji oxid měd’natý, $\mathrm{CuO}$ ), vitriolum Romanum (obvykle síran měd’natý), sanytr (dusičnan draselný, $\mathrm{KNO}_{3}$ ) a tutiji (bud' oxid, $\mathrm{ZnO}$, nebo uhličitan zinečnatý, $\mathrm{ZnCO}_{3}$ ). $\mathrm{Z}$ této směsi se měla vyrobit aqua fortis (kyselina dusičná); spíše lze očekávat směs kyselin, dusičné, sírové a siřičité a možná také lučavky královské, podle režimu pokusu. $Z$ chloridu amonného se mohly uvolňovat amonné ionty a produkt by pak obsahoval i příměs amonných solí. Další postup je složitý, ovšem už tato směs snad mohla barvit strríbro žlutě, ale zčásti by ho patrně rozpouštěla. Rovněž další tři Maierovy návody jsou podobné, jen ještě komplikovanější.

\section{Shrnutí}

Maierova De medicina je dílo cenné v řadě ohledů, počínaje skutečností, že významně doplňuje autorův životopis, známý donedávna pouze neúplně. Současně umožňuje získat představu o počátcích činnosti tohoto učence, který se považoval za ,pravého

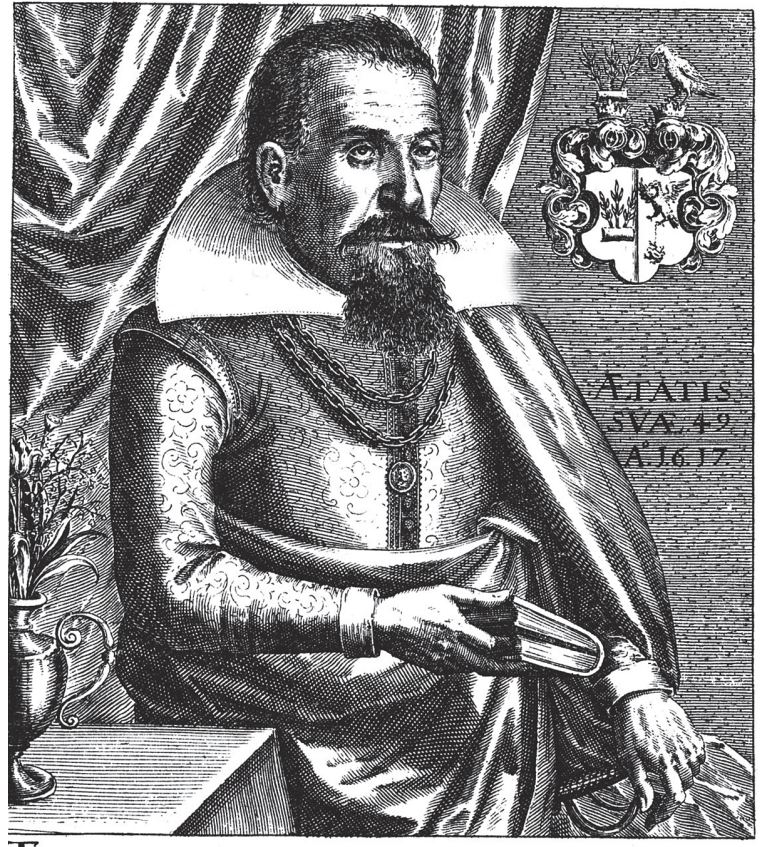

TRES SCHOLA, TRES COE SAR TITVLOS DE DIT; HAC MIHI RESTANT,

POSSE BENE IN CHRISTO VIVERE, POSSE MORI. MICHAEL MAIERVS COMES IMPERIALIS CON : SISTORII efc: PHILOSOPH: ET MEDICINARVM DOCTOR,P. C.C. NOBIL: EXEMPTVS FOR:OLIM MEDICVS CAS: efC:
Obr. 1 Portrét Michaela Maiera $\mathrm{z}$ jeho knihy Atalanta fugiens, Oppenheimi 1618 
mistra alchymie“, jak v knize připomíná. Proto také opakovaně kritizuje alchymické podvodníky, v jeho době velmi časté. Své ataky později shrnul v knize Examen fucorum pseudo-chymicorum. Podle titulu je De medicina věnována univerzálnímu léku, jehož údajně blahodárné účinky autor zmiňuje v její tř̌tí knize, ale nejpodstatnější informace, návod na výrobu tohoto preparátu, v díle chybí. Spis je zaměřen na alchymické teorie a především na praxi transmutační alchymie, a v tomto duchu se nese i několik návodů, které uvádí. Maierovo dílo také potvrzuje, že pozdně středověká Summa perfectionis magisterii, první z knih Pseudogeberova korpusu, byla velmi vlivným spisem i po třech staletích. Právem dnes o ní někteří historici píší jako o bibli alchymistů. Maier z ní však především čerpal informace o laboratorní praxi a jen velmi okrajově se zmiňoval o jejích korpuskulárních představách. Patrně byly přece jen náročné, a on byl především praktik. Potvrzuje to i fakt, že sice probral všechny hlavní teorie hmoty, s nimiž alchymie operovala, ale nelze soudit jednoznačně, zda některé z nich dával přednost. Později se Maier přikláněl k mystickým trendům, jak to dokládá jeho Atalanta fugiens, a zřejmě se postupně odkláněl od transmutační alchymie. De medicina je tak svědectvím počátků, od nichž však vedla autorova cesta jinými směry.

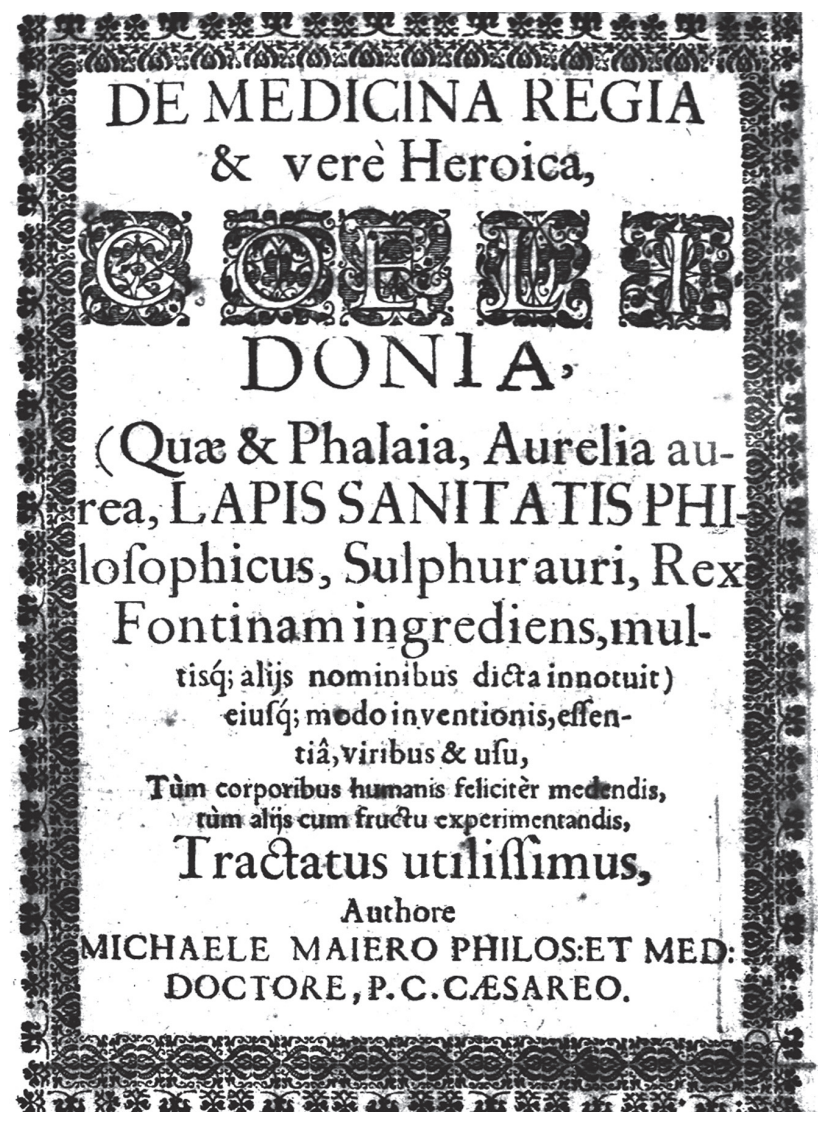

Obr. 2 Titulní list spisu Medicina regia 


\section{VLADIMÍR KARPENKO}

\section{Michael Maier und seine Schrift De medicina regia (1609)}

\section{ZUSAMMENFASSUNG}

Michael Maier (1569 Kiel - 1622 Magdeburg), ein deutscher Arzt und Alchemist, verbrachte sein Leben mit Reisen, zunächst zwecks Studien an verschiedenen Universitäten, später auf der Suche nach reichen Mäzenen. Den Doktor der Medizin erhielt er in Basel. Maier verfasste eine Reihe von Werken, das bekannteste ist sein Buch der Embleme Atalanta fugiens (1618). Sein Angriff auf betrügerische Alchemisten Examen Fucorum Pseudo-chymicorum (1617) wurde bereits früher analysiert. In vorliegendem Beitrag wendet sich Verfasser einem Frühwerk Maiers zu: der Schrift De medicina regia, die in der Königlichen Bibliothek in Kopenhagen (Royal Library in Copenhagen) entdeckt wurde. Das Werk wurde 1609 in Prag gedruckt, wo sich Maier in den Jahren 1608-1610 am Hofe Rudolphs II. aufhielt. Vom Kaiser wurde er in den Stand des Erbadels befördert, mit dem Titel comes palatinus. Er starb in Magdeburg, wo sein Archiv bei einem Stadtbrand vernichtet wurde. Der erste Teil des analysierten Werkes enthält biographische Angaben über seinen Autor, die einige Lücken in seinem Lebenslauf ergänzen. Maier erklärt, dass das Ziel seiner Arbeit die Suche nach einem universalen Heilmittel sei, welches er angeblich gefunden habe, dessen Rezept er jedoch nicht anführt. Der Hauptteil des Werkes befasst sich mit transmutaler Alchemie. Er behandelt verschiedene Theorien der Materie, mit der die Alchemie operierte, doch kann nicht eindeutig gesagt werden, ob er eine von ihnen bevorzugte. Er war eher ein Praktiker, weshalb er die Laborpraxis eingehender beschreibt. Er schöpft aus verschiedenen Quellen, vor allem aus Pseudogeber und seiner Summa perfectionis magisterii. Auch weist er nach, dass diese spätmittelalterliche Arbeit auch nach drei Jahrhunderten noch eine sehr einflussreiche Schrift ist. Mit Recht wird sie heute von einigen Historikern als die Bibel der Alchemie bezeichnet. Maiers De medicina ist in mehrfacher Hinsicht ein wertvolles Werk. Es ermöglicht, eine Vorstellung über die anfängliche Tätigkeit dieses Gelehrten zu gewinnen, der sich für einen ,echten Meister der Alchemie“ hielt, wie er sich in dem Buch selbst bezeichnet. Später neigte Maier mystischen Trends zu, was seine Atalanta fugiens belegt, und nahm offensichtlich allmählich Abstand von der transmutalen Alchemie.

Deutsche Übersetzung Wolf B. Oerter

Vladimír Karpenko

Katedra fyzikální a makromolekulární chemie

Přrrodovědecká fakulta Univerzity Karlovy

karpenko@natur.cuni.cz 